УДК 82I.I6I.I+82I.I33.I ББК $83.3(2 \mathrm{Poc}=\mathrm{Pyc}) 53^{+}$ $83.3(4 \Phi$ ра $) 5 \mathrm{I}$

\section{РАСИН И МАНДЕЛЬШТАМ}

(C) 2017 г. М.Ю. Игнатьева (Оганисьян)

Православный Свято-Тихоновский гуманитарный университет,

Москва, Россия

Дата поступления статьи: 9 марта 2017 г.

Дата публикации: 25 сентября 2017 г.

DOI: I0.22455/2500-4247-20I7-2-3-204-2I9

Аннотация: Статья представляет собой фрагмент кандидатской диссертации «Философско-эстетические принципы трагедии Кальдерона и Расина», защищенной на кафедре истории зарубежной литературы МГУ в г988 г. Автор стремился к тому, чтобы рассмотреть расиновскую тему у Мандельштама в контексте теории трагического. В статье, эссеистичной по форме, последовательно анализируются основные образы и ключевые понятия изучаемой темы: ниспадающая шаль как образ тяжести-легкости («Спадают с плеч классические шали»), слово-признание как выражение искупленного, очищенного страдания («Слово - чистое веселье, // Избавленье от тоски»), смерть через слово к освобождению («Зловещий голос горький хмель - // Душа расковывает недра») и др. Особое внимание уделено образу «черного солнца», «запятнанного дня» расиновской Федры, этот образ полон различных коннотаций, он «не выбрасывает из себя готового смысла» («Разговор о Данте»). У Расина Солнце - сакральный символ, «Бог сокровенный» - Deus absconditus янсенизма: греховность Федры пятнает солнце, делает его черным. Предсмертные слова Федры утверждают искупительный смысл ее гибели. В статье «Пушкин и Скрябин» Мандельштам пишет о трагическом смысле гибели художника и сопоставляет ее с подвигом Федры. Взгляд на расиновское присутствие у Мандельштама с учетом исследований таких знатоков Расина, как Р. Барт, Л. Гольдманн, Ж. Пуле и др., позволяет лучше понять и прямые, и косвенные расиновские аллюзии у Мандельштама, а также его взгляд на трагедию и трагическое c I9I4 по I920 г., когда поэт читал и переводил великого французского трагика, и осмыслял те трагические события, свидетелем которых он стал.

Ключевые слова: Мандельштам, Расин, трагическое, трагедия, черное солнце, Скрябин.

Информация об авторе: Мария Юльевна Игнатьева (Оганисьян) - кандидат филологических наук, доцент, Православный Свято-Тихоновский гуманитарный университет, ул. Иловайская, д. 9, стр. 2, Іо965г Москва, Россия.

E-mail: maria.ignatieva@gmail.com 


\title{
RACINE AND MANDELSTAM
}

\author{
(C) 20I7. M.Yu. Ignatieva (Oganisyan) \\ St. Tikhon's Orthodox University, \\ Moscow, Russia \\ Received: March 9, 2017 \\ Date of publication: September 25, 2017
}

This is an open access article

distributed under the Creative

Commons Attribution 4.0

International (CC BY 4.0)

Abstract: This article is a fragment of the PhD thesis Philosophical and Aesthetic Principles of Tragedy in Calderon and Racine (Department of the History of Foreign Literature, Moscow State University, I988). In her dissertation, the author examined Racine's presence in Mandelstam's poetry against the theory of the tragic. Written in the essayistic form, the article examines the following basic images and key concepts of this general theme: (I) cascading shawls as emblematizing heaviness / lightness; (2) a word-confession as expression of pure and redemptive suffering; (3) death by word followed up by redemption. It pays particular attention to the image of the "black sun" and the "tainted day" in Racine's Phaedra. According to Mandelstam, this image has different connotations and "does not evoke a ready-made meaning" ("Conversation about Dante”). In Racine, Sun is a sacred symbol, it is "the Hidden God”, or Deus absconditus of Jansenism. Phaedra's sin stains the Sun and darkens it. Phaedra's last words confirm the redemptive effect of her death. In the article "Pushkin and Scriabin," Mandelstam writes about the tragic meaning of the artist's death and compares it with Phaedra's deed. The study of Racine's presence in Mandelstam, taking into account the studies of such scholars as Barthes, Goldmann, Poulet and others, allows us to point out explicit and implicit allusions to Racine in Mandelstam's poetry. It also helps to understand Mandelstam's idea of the tragedy and the tragic as it developed from I9I4 through I920 when the poet was translating the great French tragedian and at the same time was trying to comprehend the tragic events he witnessed.

Keywords: Mandelstam, Racine, tragic, tragedy, black sun, Scriabin.

Information about the author: Maria Yu. Ignatieva (Oganisyan), $\mathrm{PhD}$ in Philology, Associate Professor, St. Tikhon's Orthodox University, Ilovaiskaya 9-2, I0965I Moscow, Russia.

E-mail: maria.ignatieva@gmail.com 
Тому не быть - трагедий не вернуть, Но эти наступающие губы, Но эти губы вводят прямо в суть Эсхила-грузчика, Софокла-лесоруба.

Быть может, прежде губ уже родился шепот...

И в наказанье за гордыню, неисправимый звуколюб,

Получишь уксусную губку ты для изменнических губ ${ }^{\mathrm{I}}$.

Губам самим корневым основанием свойственна уксусная губка, как шепот, как стихиㄴ․ Такова метафизика поэзии по Мандельштаму.

В его поэтике важное место занимает то, что мы бы назвали «образ-движение» или «образ движения» - знак чужого присутствия. Например, Вийона: «Размотавший на два завещанья // Слабовольных имуществ

I Произведения Мандельштама цит. по: [г].

2 Данная статья представляет собой фрагмент диссертации на соискание ученой степени кандидата наук «Философско-эстетические принципы трагедии Кальдерона и Расина», защищенной на кафедре зарубежной литературы МГУ им. М.В. Ломоносова в I988 г. Эссе было включено в диссертацию в качестве приложения. Этим объясняется отсутствие ссылок на позднейшие исследования и переводы. 
клубок»... Или Данте: «Легче было вам, Дантовых девять, // Атлетических дисков, звенеть».

Движение у Расина - спадающая классическая шаль.

\section{І. «СПАДАЮТ С ПЛЕЧ КЛАССИЧЕСКИЕ ШАЛИ»}

Самый весомый и полнозвучный для Мандельштама стих «Федры»:

Que ces vains ornements, que ces voiles me pèsent!

(Как давят на меня эти украшения, эти шали!)

Парадоксальный образ (тяжесть легких покрывал) органично перешел в поэзию Мандельштама, и не только в стихи-реминисценции из «Федры»: образ тяжести (и дальше - тяжести-беременности, тяжести-нежности, тяжести-легкости) во всех стихах, где он появляется, несет в себе воспоминание о «Федре».

Но чем внимательней, твердыня Notre Dame,

Я изучал твои чудовищные ребра,

Тем чаще думал я: из тяжести недоброй

И я когда-нибудь прекрасное создам.

С такой определенной любовью к плодородной тяжести (из недоброй - прекрасное, а легкое - тяжело: «И колесо вращается легко») Мандельштам не мог не восхититься в двойственном и парадоксальном Расине этой строкой, которую так любовно примерял к русской речи. Кажется, что он не закончил перевода «Федры» только потому, что до этого стиха надо было пробираться еще через две сцены.

Образы у Мандельштама наполнены (полонены) плотью: они воспринимаются на глаз, на слух, на вкус. Расиновские образы конкретны весомостью, тяжестью: 
Спадая с плеч, окаменела

Ложно-классическая шаль.

Как этих покрывал и этого убора

Мне пышность тяжела средь моего позора!

Его Трезен ощутимо каменный. Мандельштам одел в камень ту замкнутость трагического пространства, которую почувствовал и Ролан Барт [2].

Будет в каменной Трезене

Знаменитая беда.

Царской лестницы ступени

Покраснеют от стыда. (I9I6)

Даже в переведенном отрывке из «Федры» у Мандельштама появляется образ трезенских стен, которого в подлиннике нет.

Le dessein en est pris, je pars, cher Théramène,

Et quitte le séjour de l'aimable Trézène.

(Решение принято, я уезжаю, дорогой Терамен, // И покидаю любезный Трезен).

Решенье принято, час перемены пробил!

Узор трезенских стен всегда меня коробил.

Ясно, что в названии первой книги Осипа Мандельштама - «Камень» - обозначена и расиновская тема. Однако ключевое стихотворение к пониманию этой темы содержится во второй книге - Tristia. Это «Сестры тяжесть и нежность» (1920).

Ах, тяжелые соты и нежные сети,

Легче камень поднять, чем имя твое повторить! 
У меня остается одна лишь забота на свете:

Золотая забота, как времени бремя избыть.

Мы уже сказали, что образ тяжести, как бы по-разному он ни был воплощен, у Мандельштама всегда расиновский (хотя и не только расиновский). Тяжесть - это безмолвие. Слово - освобождение.

Божье имя, как большая птица,

Вылетело из моей груди.

Впереди густой туман клубится,

И пустая клетка позади.

Слово - чистое веселье,

Избавленье от тоски.

(I9I5)

(Запомним эти последние стихи, написанные в том году, к которому относится начало прямых реминисценций из «Федры» в стихах Мандельштама; мы к ним позже вернемся, а пока важно понимать их как выражение не чистого веселья, но веселья как искупленного, очищенного страданья.)

Сказать слово («имя повторить») тяжелее, чем камень поднять. Каменные шали сковывают, но жизнь разрешена. Слово же - это умирание, избывание бремени (=тяжести) жизни (=времени) [г, с. 66]. Следуя цепочке инверсий, приходим к такому уравнению:

слово = избывание тяжести - избывание времени - умирание $=$ чистое веселье.

Смерть через слово к освобождению, чистоте - таков вектор трагического у Расина, и Мандельштам точно определяет его:

Зловещий голос - горький хмель -

Душа расковывает недра:

Так - негодующая Федра -

Стояла некогда Рашель. 
Действительно, высшее мгновение Федры - то, когда она произносит Слово. Это равнозначно освобождению от тяжести, но по ту сторону уравнения - смерть. Или наоборот: сказать Слово значит погубить себя, но и - вину искупить, сбросить каменные покрывала, вернуть чистоту (веселья - у Мандельштама, дня - у Расина).

Спадают плеч классические шали.

Расплавленный страданьем крепнет голос

И достигает скорбного закала

Негодованьем раскаленный слог.

Вот это расиновское движение у Мандельштама: спадают - крепнет - достигает. От тяжести к освобождению от нее; от безмолвия к слову; через смерть к чистоте.

\section{II. «ЭТО СОЛНЦЕ НОЧНОЕ ХОРОНЯТ»}

Мы попытались показать расиновский жест у Мандельштама. Этот жест-образ синхронен трагическому движению - движению к развязке, к гибели, к искуплению, т. е. центростремительному движению к трагедии. Характерно, что этот образ парадоксален, двулик (тяжесть и легкость). Но такая двойственность является, скорее, одним ликом двух начал: «Сестры - тяжесть и нежность - одинаковы ваши приметы». Противоречивое, парадоксальное у Мандельштама (и у Расина - ср., например, такое существенное понятие поэтики Расина, как герой-двойник [4], скреплено одной кровной связью: не разнородность, но двоюродность).

Теперь мы можем перейти к главному расиновскому образу у Мандельштама - «черное солнце». Известно, что это один из любимых образов Мандельштама, имеющий множество литературных, философских, религиозных и других источников. Интересно, что, развивая мысль о том, что слово несет в себе множество импульсов к «припоминанию» его смысла неоднозначного, «пучкообразного», Мандельштам в «Разговоре о Данте» приводит пример именно с солнцем: «Когда мы произносим, например, 
“солнце”, мы не выбрасываем из себя готового смысла, - это был бы семантический выкидыш, - но переживаем своеобразный цикл». Образ солнца в поэзии Мандельштама не просто ведет за собой широкий круг культурноисторических ассоциаций, он и внутри отдельного аспекта он не однозначен, не «выбрасывает из себя готового смысла». Так «черное солнце» Расина у Мандельштама связано с картиной пушкинских похорон, причем так тесно, что подчас трудно сказать, когда речь идет о Расине, когда - о Пушкине. Вернемся к стихотворению «Сестры - тяжесть и нежность». Оно начинается строфой, которая подтверждает нашу мысль о том, что это стихотворение - расиновское, и, шире, что образ тяжести у Мандельштама всегда реминисценция из Расина:

Сестры - тяжесть и нежность - одинаковы ваши приметы.

Медуницы и осы тяжелую розу сосут.

Человек умирает, песок остывает согретый,

И вчерашнее солнце на черных носилках несут.

То, что эти стихи о Пушкине, доказывает фрагмент из статьи «Пушкин и Скрябин», о которой подробно речь пойдет ниже. Пушкин был для Мандельштама солнечным поэтом:

\section{Стояло солнце Александра}

Сто лет назад, сияло всем...

Но Солнце - ночное, Солнце похороненное. Цветаевское «с проходного двора - умнейшего мужа России» перекликается с темой похорон Солнца у Мандельштама. «И вчерашнее солнце на черных носилках несут» - пластический образ носилок здесь выражает связь двух образов: тяжесть и черное солнце. Черное - потому что вчерашнее, потому что ночное, потому что хоронится чернью. К этому нас подводит возможная интерпретация стихотворения «В Петербурге мы сойдемся снова» (г20) в аспекте пушкинско-расиновской темы у Мандельштама. В Петербурге, поглотившем солнце, в черном «бархате всемирной пустоты», в ночи черной, в ночи черни остается только молиться «за блаженное бессмысленное слово», ко- 
торое одно - искупление. Петербург - это могила солнца (вспомним из другого стихотворения: «В Петербурге жить - словно спать в гробу», I93I), это театр, доставшийся «черным душам и низменным святошам». В стихотворении «Я не увижу знаменитой «Федры» Мандельштам скажет: «Уйдем, покуда зрители-шакалы // На растерзанье Музы не пришли». И здесь тот же мотив ухода: «Что ж, гаси, пожалуй, наши свечи». Ср.: «Когда бы грек увидел наши игры» - при сопоставлении двух стихов из разных стихотворений становится понятным двойной смысл каждого: признание того, что игры общие, и трагическая невозможность выйти из игры иначе, как через Слово; но оно - гибель. Тема черни проходит почти через все расиновские стихи Манделыптама. С ней связан и тот факт, что образ солнца всегда появляется в обстановке похорон. Но образ самого солнца меняет значения. Рассмотрим некоторые из них в контексте расиновской темы.

Во-первых, солнце - это сама трагедия Расина, это солнце вчерашнее, похороненное. «Я опоздал на празднество Расина». Главное здесь отделение себя от черноты-пустоты, уход, отказ от участия в играх черни. Приведем полностью стихотворение I9I8 г., демонстрирующее этот аспект расиновской темы.

Когда в темной ночи замирает

Лихорадочный форум Москвы,

И театров широкие зевы

Возвращают толпу площадям,

Протекает по улицам пышным

Оживленье ночных похорон,

Льются мрачно - веселые толпы

Из каких-то божественных недр.

Это солнце ночное хоронит

Возбужденная играми чернь, Возвращаясь с полночного пира

Под глухие удары копыт. 
И как новый встает Геркуланум,

Спящий город в сияньи луны,

И убогого рынка лачуги,

И могучий дорический ствол.

Но такой аспект темы является как бы внешним по отношению к самой трагедии. Это восприятие ее извне, из театральной ложи. Но вот снимаются кавычки, и уже не «Федра», а сама героиня трагедии - черное похороненное солнце, солнце черной страсти, солнце-ночь. Этой линии у Мандельштама созвучны концепция и терминология Р. Барта. Барт говорит, что вся трагедия Расина строится на конфликте тени и света. «Федра, дочь Солнца, пылает страстью к Ипполиту, человеку тени - растительной, лесной» [2, с. 28]. «Рожденное чаще всего вместе с самой трагедией (которая - день), солнце становится смертоносным одновременно с нею». Солнце, по Барту, это взрыв, ослепление, пожар, кризис. Солнечные персонажи у Расина - цари, императоры, т. е. те, кто наделен властью; природа тени плен, зависимость. Но имеющий власть любит своего пленника, а пленник не любит того, от кого зависит. Солнце преследует тень, пронзает ее, разрушает и губит. Однако Солнце иногда пытается себя сдерживать, смирять и умерять, тогда оно «приобретает парадоксальное свойство: сияние. Но сияние это не обязательно качество собственно света, это состояние материи: существует и сияние ночи» [2, с. 3I].

Сравним с двумя строфами из мандельштамовского стихотворения, построенного на перебивании двух планов: классического (еврипидовского) и ложноклассического (расиновского), что передает драматизм сияния черного солнца, конфликт дня (Ипполита) и ночи (Федры). Приводимые ниже стихи имитируют голос античного хора:

- Черным пламенем Федра горит

Среда белого дня.

Погребальный факел чадит

Среди белого дня.

Бойся матери ты, Ипполит:

Федра - ночь - тебя сторожит

Среди белого дня. 
- Мы боимся, мы не смеем

Горю царскому помочь.

Уязвленная Тезеем

На него напала ночь.

Мы же песнью похоронной

Провожая мертвых в дом,

Страсти дикой и бессонной

Солнце черное уймем.

Нетрудно заметить, как тесно соприкасаются эти стихи со страницей Барта: день трагедии; Федра - «ночь» (ночное солнце), сторожащая Ипполита. «Погребальный факел» символизирует не только приближающуюся гибель Ипполита, но и гибель самой Федры. Ее образ для Мандельштама неотделим от представления о ее гибели, поэтому за ним всегда следует образ похорон.

В процитированных строках интересно настойчивое противопоставление черного и белого. Оно, во-первых, подчеркивает виновность Федры - по контрасту с невинностью Ипполита; а во-вторых, означает (и здесь мы подходим к основному значению солнца у Расина), что черная любовь Федры оскорбляет чистоту небес. Между этими строфами у Мандельштама один стих «из Расина»:

- Любовью черною я солнце запятнала.

Солнце - сакральный символ, «Бог сокровенный» - Deus absconditus янсенизма [3]. Греховность Федры пятнает солнце, делает его черным. Предсмертные слова Федры утверждают искупительный смысл ее гибели.

Et la mort, a mes yeux dérobant la clarté

Rend au jour qu'ils souillaient toute sa pureté.

(И смерть, скрывая свет от моих глаз, // Возвращает дню, что они запятнали, всю его чистоту). 
Наиболее убедительная, на наш взгляд, интерпретация этих стихов, принадлежащая французскому критику Жоржу Пуле, созвучна представлению Мандельштама І9Іо-І920-х гг. о смысле смерти (об этом ниже): «Мне, мой Бог, говорит Федра, как мне безразлично, что меня больше не будет, потому что ты не перестанешь быть, и быть тем, кто очищает пятна мира, но пусть пятна мира больше не пятнают» [5, с. II9].

Итак, «солнечность» - это категория священного, которое проявляется в разных формах: черное солнце «Федры», солнце «черной страсти» Федры, солнце - Бог, запятнанный черной любовью Федры.

\section{III. «МИФ О ЗАБЫТОМ ХРИСТИАНСТВЕ»}

«И вчерашнее солнце на черных носилках несут». Авторская расшифровка этого образа - в статье «Пушкин и Скрябин» (I9I5): «Пушкина хоронили ночью. Хоронили тайно. Мраморный Исаакий - великолепный саркофаг - так и не дождался солнечного тела поэта. Ночью положили солнце в гроб, и в январскую стужу проскрипели полозья саней, увозивших для отпевания прах поэта» [г, с. 48].

Солнце, похороненное чернью в черноте ночи, - это солнце Пушкина. И солнце Федры: «Я вспоминаю картину пушкинских похорон, чтобы вызвать в вашей памяти образ ночного солнца, образ последней греческой трагедии, созданной Еврипидом, - видение несчастной Федры». Это солнце эллинское.

Тинслей в лекции «Христианская теология и границы трагедии» говорит: «Для греков трагедия человека неминуема: его жизнь - постоянный объект “ревности богов” [6, с. 7]. Прихоть богини сделала до сих пор невинную Федру участницей (орудием) гибели Ипполита. Поэтому она виновна. Эллинское солнце - солнце вины.

...мы вознесли над собой Скрябина, чье солнце-сердце горит над нами, но - увы! - это не солнце искупления, а солнце вины. Утверждая Скрябина своим символом в час мировой войны, Федра-Россия...

дальше текст не сохранился). Но это солнце остается эллинским до тех пор, пока не становится солнцем искупления. 
Если сорвать покров смерти с этой творческой жизни, она будет свободно вытекать из своей причины - смерти, располагаясь вокруг нее, как вокруг своего солнца, и поглощая его свет.

Смерть «безумствующего эллина» Скрябина, смерть этого черного солнца вины возвращает ему чистоту и сияние христианства. Христианство, по Мандельштаму, это Эллада, возведенная на Голгофу. «Рим железным кольцом окружил Голгофу: нужно освободить этот холм, ставший греческим и вселенским. Римский воин охраняет распятье и копье наготове: сейчас потечет вода: нужно удалить римскую стражу... Бесплодная, безблагодатная часть Европы восстала на плодную, благодатную. Рим восстал на Элладу... Нужно спасти Элладу от Рима. Если победит Рим - победит даже не он, а иудейство - иудейство всегда стояло за его спиной и только ждет своего часа и восторжествует страшный противуестественный ход: история обратит течение времени - черное солнце Федры».

Попробуем скрепить новую цепочку мандельштамовских соответствий: течение времени - черное солнце Федры - солнечная тяжесть, положенная на черные носилки - избываемое времени бремя.

У меня остается одна лишь забота на свете:

Золотая забота, как времени бремя избыть.

Избыть это бремя можно только умерев. Точнее, это избывание и есть сама смерть. Сказать имя для Мандельштама значит вспомнить имя. В его статье можно найти еще одно звено для этой цепочки, которое мы уже восстанавливали на материале расиновских стихотворений Мандельштама: сказать слово - умереть. Но сказать - значит вспомнить, значит умереть: «С легкого, хрупкого лица спадает маска забвения, проясняются черты; торжествует память - пусть ценою смерти: умереть значит вспомнить, вспомнить - значит умереть». Ценою смерти! Но - и в этом все «веселье», вся «нежность» не смерти эллинской, не смерти ветхозаветной («Всему и всем - одно: одна участь праведнику и нечестивому... они отходят к умершим», Еккл. 9: 2), но смерти христианской: от вины к искуплению, от смерти к бессмертию, через Слово-плоть. 
«Дух греческой трагедии проснулся в музыке. Музыка совершила круг и вернулась туда, откуда вышла: снова Федра кличет кормилицу, снова Антигона требует погребения и возлияния для милого братнего тела».

... Долго, долго мы играли с музыкой, не подозревая опасности, которая в ней таится, и пока - быть может, от скуки - мы придумывали миф, чтобы украсить свое существование, музыка бросила нам миф - не выдуманный, а рожденный, пенорожденный, багрянорожденный, царского происхождения, законный наследник мифов древности - миф о забытом христианстве.

Возвращением христианского мифа, по Мандельштаму, музыка обязана Скрябину. Его смерть «есть высший акт его творчества», потому что именно ее ценою художник преодолел забвение и вспомнил забытый миф. Но не полна ли такого же значения и гибель Федры? - нет, не Федры Еврипида, но Федры христианского поэта? Это уже Федра Расина кличет кормилицу. Та Федра, солнце-сердце которой в разгар мировой войны для Мандельштама было символом «эллинизированной смерти». «Эллинство, оплодотворенное смертью, и есть христианство». Таково значение гибели, по Мандельштаму. Бог в «Федре» мифологический, но - христианский. Барт считает, что единственный, настоящий расиновский бог «ни греческий, ни христианский», это Бог Ветхого Завета в своей буквальной и почти эпической форме: это Яхве [2, с. 50]. Дело, нам кажется, в том, что Барт рассматривает смерть трагического героя только в рамках структуралистского анализа: смерть - единственный возможный выход из трагического пространства. Смерть как творческий акт, полный смысла и величия, существует только в христианстве.

Теперь понятно, почему «черное солнце» Федры у Мандельштама всегда солнце похороненное. Умирая, Федра обретает свое высшее мгновение. Это искупительная жертва Солнцу, приобщение страданиям Христа.

Рассмотренные примеры дают представление о некоей единой теме, пронизывающей творчество поэта приблизительно с I9I4 по I920 г. 3 B последующие годы эта тема с присущим ей романтическим трагизмом, вероятно навеянным стихами и прозой Вяч. Иванова (ср. рассуждения Иванова

3 Здесь же можно было бы вспомнить стихи, посвященные Анне Ахматовой («Ахматова», 1914, «Кассандре», 1917, и др.), они также полны расиновских аллюзий. 
о трагедии, его статьи о Скрябине), уступит место предметам «правдивей и страшнее», однако, ее отголоски будут слышны и в поздних стихах («Не искушай чужих наречий», «Да, я лежу в земле, губами шевеля» и др.).

\section{Список литературы}

I Мандельштам О.Э. Собр. соч.: в 4 т. Вашингтон; Париж: Международное Литературное содружество, I967-I98I. 599 с. +737 с. + 55I с. + 203 с.

2 Barthes R. Sur Racine. Paris: Seuil, I963. I66 p.

3 Goldmann L. Le Dieu caché. Étude sur la vision tragique dans les "Pensées" de Pascal et dans le théâtre de Racine. Paris: Gallimard, I959. 454 p.

4 Mauron Ch. L'Inconscient dans l'oeuvre et la vie de Racine. Gap: Ophrys, I957. 350 p.

5 Poulet G. Notes sur le Temps racinien // Poulet G. Etudes sur le temps humain. P.: PIon, I949. T. I. P. I04-I2I.

6 Tinsley $B$. Christian theology and the frontiers of tragedy. Cambridge: Leeds univ. press, I963. $25 \mathrm{p}$. 


\section{References}

I Mandelstam O.E. Sobranie sochinenii: $v 4 t$. [Complete works: in 4 vols.]. Washington, Paris, Mezhdunarodnoe Literaturnoe sodruzhestvo Publ., I967-I98I. 599 p. + 737 p. + 55I p. + 203 p. (In Russ.)

$2 \quad$ Barthes R. Sur Racine. Paris, Seuil, I963. I66 p. (In French)

3 Goldmann L. Le Dieu caché. Étude sur la vision tragique dans les “Pensées” de Pascal et dans le théâtre de Racine. Paris, Gallimard, I959. 454 p. (In French)

4 Mauron Ch. L'Inconscient dans l'oeuvre et la vie de Racine. Gap, Ophrys, I957.350 p. (In French)

5 Poulet G. Notes sur le Temps racinien. Poulet G. Etudes sur le temps humain. Paris, PIon, I949, t. I, pp. I04-I2I. (In French)

6 Tinsley B. Christian theology and the frontiers of tragedy. Cambridge, Leeds univ. press, I963. 25 p. (In English) 